\title{
Description of new Ceratitis species (Diptera: Tephritidae) from Africa, or how morphological and DNA data are complementary in discovering unknown species and matching sexes
}

\author{
Marc DE MEYER ${ }^{1 *}$, Maulid MWATAWALA ${ }^{2}$, Robert S. COPELAND ${ }^{3} \&$ \\ Massimiliano VIRGILIO ${ }^{4}$ \\ ${ }^{1,4}$ Royal Museum for Central Africa, Department Biology \& JEMU, Tervuren, Belgium. \\ ${ }^{2}$ Sokoine University of Agriculture, Department of Crop Science and Production, Morogoro, Tanzania. \\ ${ }^{3}$ International Centre of Insect Physiology and Ecology, Nairobi, Kenya. \\ *Corresponding author: marc.de.meyer@africamuseum.be \\ ${ }^{2}$ Email: mwatawala@yahoo.com \\ ${ }^{3}$ Email: rcopeland@, icipe.org \\ ${ }^{4}$ Email: massimiliano.virgilio@africamuseum.be \\ ${ }^{1}$ urn:1sid:zoobank.org:author:2F07B9E7-3545-49DE-8C72-55E8ED95A455 \\ ${ }^{2}$ urn:Isid:zoobank.org:author:F61E74AB-FABD-4347-A125-64C5C5F7F241 \\ ${ }^{3}$ urn:lsid:zoobank.org:author:F2F7C761-2E36-4DAB-9EDF-091220DA8A88 \\ ${ }^{4}$ urn:Isid:zoobank.org:author:A4C7D3FF-E127-4645-9BFD-78222520FE26
}

\begin{abstract}
This paper describes five new Ceratitis species from the eastern and southern parts of the Afrotropical Region: C. (Pterandrus) quilicii De Meyer, Mwatawala \& Virgilio sp.nov.; C. (Ceratalaspis) pallidula De Meyer, Mwatawala \& Virgilio sp. nov.; C. (Ceratalaspis) taitaensis De Meyer \& Copeland sp. nov.; C. (Ceratalaspis) sawahilensis De Meyer \& Virgilio sp. nov.; and C. (Ceratalaspis) flavipennata De Meyer \& Virgilio sp. nov. Their relationships with closely allied species within their respective subgenera are discussed where appropriate, and diagnostic characters are given. DNA barcodes are provided for all new species. In addition, the hitherto unknown male of $C$. (Pardalaspis) serrata De Meyer, 1996 is described, based on material collected in the Democratic Republic of Congo. Recognition of these new species and sexes is the result of an integrative approach using morphological characters and DNA data.
\end{abstract}

Keywords. Fruit flies, Afrotropical, DNA barcoding.

De Meyer M., Mwatawala M., Copeland R.S. \& Virgilio M. 2016. Description of new Ceratitis species (Diptera: Tephritidae) from Africa, or how morphological and DNA data are complementary in discovering unknown species and matching sexes. European Journal of Taxonomy 233: 1-23. http://dx.doi.org/10.5852/ejt.2016.233

\section{Introduction}

Tephritidae are picture-winged flies of variable size and worldwide distribution. Although commonly named "fruit flies", larval development can also take place in other parts of the host plants, including 
flowers, seeds, leaves and stems. Fruit flies of economic significance were treated by White \& ElsonHarris (1994), and the currently acknowledged classification was presented by Norrbom et al. (1999). The genus Ceratitis MacLeay, 1829 belongs to the tribe Ceratitidini, which is predominantly an Afrotropical group and comprises 95 described species. The larvae of Ceratitis develop in fruit, and several species of agricultural importance are known from this genus including the Mediterranean fruit fly (Ceratitis capitata (Wiedemann, 1824)), and the Natal fruit fly (Ceratitis rosa Karsch, 1887). The taxonomy of the different subgenera within the genus Ceratitis has been revised in the last two decades (De Meyer 1996, 1998, 2000; De Meyer \& Copeland 2001; De Meyer \& Freidberg 2006), and additional descriptions of species were presented after the publication of these revisions (De Meyer \& Copeland 2005, 2009). Virgilio et al. (2014) provided an electronic identification key for all known species, as well as for representatives of related genera. The key was recently updated to include the newly described Ceratitis species (available from http://fruitflykeys.africamuseum.be).

\section{Material and methods}

The material included in this paper has been studied within the framework of a number of recent fruit fly related projects, including surveying activities in different parts of Africa and integrated pest management (IPM) related collaborative projects in Tanzania. During these studies a number of hitherto unknown species were encountered. A case in particular is the description of $C$. quilicii sp. nov. This is the result of an integrative taxonomic study on a number of cryptic species complexes of economic significance (Hendrichs et al. 2015), including the Ceratitis FAR complex (Barr \& Wiegmann 2009; Virgilio et al. 2008).

Material from the following collections was studied:

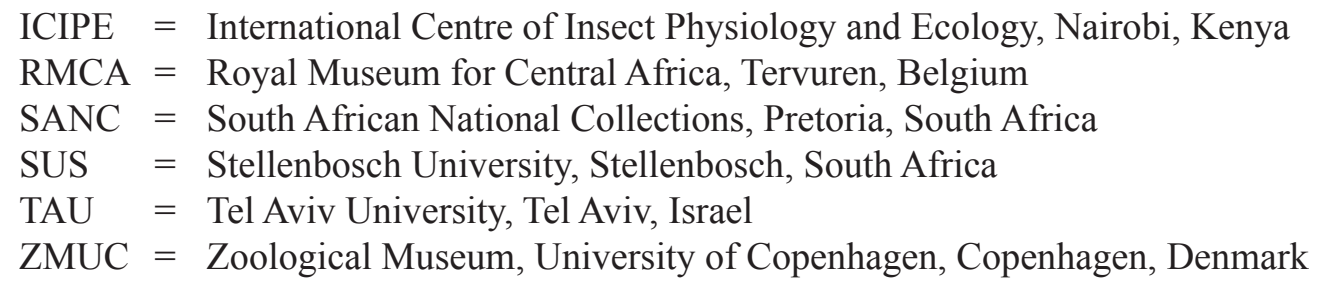

In the species descriptions, terminology follows the glossary of White et al. (1999). Wing and body (without oviscape for females) length were taken for ten specimens unless less were available, and are given in $\mathrm{mm}$ (average and range). Measurements of both sexes were pooled (where applicable) since no sexual difference was noted. Images of body parts were taken using a digital camera mounted on a Leica MZ12 dissecting microscope and using Automontage software (Syncroscopy, UK). Female terminalia were dissected, cleared in potassium hydroxide solution and temporarily mounted in glycerinegelatine for drawings made by camera lucida. A set of DNA sequences were produced for part of the mitochondrial Cytochrome c oxidase subunit I (COI) and deposited in the Barcode of Life Data Systems (BOLD, http://www.boldsystems.org) as reference DNA barcodes for the molecular identification of the new species (see Virgilio et al. 2012 for laboratory protocols and discussion). Kimura's two parameter genetic distances (Kimura 1980) between the newly generated Ceratitis DNA barcodes and a selection of 367 reference DNA barcodes deposited in BOLD (corresponding to 51 species from all six Ceratitis subgenera) were visualized in a neighbor joining tree. In addition to the above mentioned depositories, the following acronyms are used to indicate institutions where type material is deposited:

$\mathrm{BMNH}=$ Natural History Museum (London, UK)

NMK = National Museums of Kenya (Nairobi, Kenya)

SUA = Sokoine University of Agriculture, Department of Crop Science and Production (Morogoro,Tanzania)

USNM = National Museum of Natural History, Smithsonian Institution (Washington DC, USA) 


\title{
Results
}

\author{
Phylum Arthropoda Siebold, 1884 \\ Class Insecta Linnaeus, 1758 \\ Order Diptera Linnaeus, 1758 \\ Family Tephritidae Macquart, 1835 \\ Subfamily Dacinae Schiner, 1864 \\ Tribe Ceratitidini Bezzi, 1910 \\ Genus Ceratitis MacLeay, 1829
}

Ceratitis (Pterandrus) quilicii De Meyer, Mwatawala \& Virgilio sp. nov. urn:1sid:zoobank.org:act:FE85EC42-12F6-4C76-80C2-CA8A7C4E7D5D

Fig. 1

\section{Etymology}

Named in honour of the late Dr. Serge Quilici (Centre de Coopération Internationale en Recherche Agronomique pour le Développement, CIRAD, La Réunion) who passed away in 2015. The species name should be treated as a noun in the genitive case.

\section{Material examined}

Holotype

TANZANIA: §’, Nyandira, EGOlure trap, 4 May 2013, M. Mwatawala (RMCA coll Nr T19315).

Paratypes (deposited in BMNH, NMK, RMCA, SANC, SUA, and USNM)

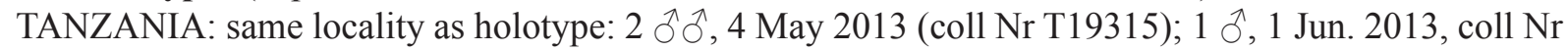
T19471; 2 ठ̊

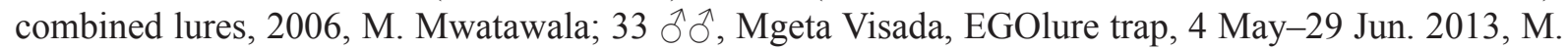
Mwatawala.

KENYA: $2 \precsim \widehat{\jmath}$, Kirimiri Forest, reared ex fruits Englerophytum natalense, 23 Jan. 2002, coll Nr1683; 1 ô, Kirimiri Forest, reared ex fruits Englerophytum natalense, 21 Jan. 2003, coll Nr 2380, all R.S. Copeland.

\section{Non-type material} BOTSWANA: Gaborone.

KENYA: Embu-Runyenjes; Kirimiri Forest; Taita Hills, near Ngangao Forest.

MALAWI: Bvumbwe Research Station; Kumbali; Zomba.

RÉUNION ISLAND: St. Pierre.

SOUTH AFRICA: Addo; Arnoldton; Baltimore; Bavaria; Bloemfontein; Bonza Bay; Britstown; Burgershall; Cato Manor; Cedara; Citrusdal; Clanwilliam; Doreen Clark Nature Reserve; Duivelskloof; Dukuduku; Durban; East London; Enon Farm, near Richmond; Eshowe; Ferncilff Nature Reserve; Fort Beaufort; Gariepdam; Grahamstown; Haenertsburg; Wyllie's Poort, Ingwe Motel; Jan Kempdorp; King William's Town; Kirkwood; Knysna; Komatipoort; Kruger National Park; Kwambonambi; Louis Trichardt; Lynnwood; Malipsdrift; Marble Hall; Nelspruit; Nkandla; Nkwalini; Olifantshoek; Onrus River; Paarl; Pienaarspoort; Pietermaritzburg; Piketberg; Port Elizabeth; Port Shepstone; Porterville; Pretoria; Riebeek Kasteel; Roodeplaat; Rustenburg; Somerset West; Stellenbosch; Tshipise; Tzaneen; Uitenhage; Volksrust; Vryburg; Warner Beach; Wynberg. 


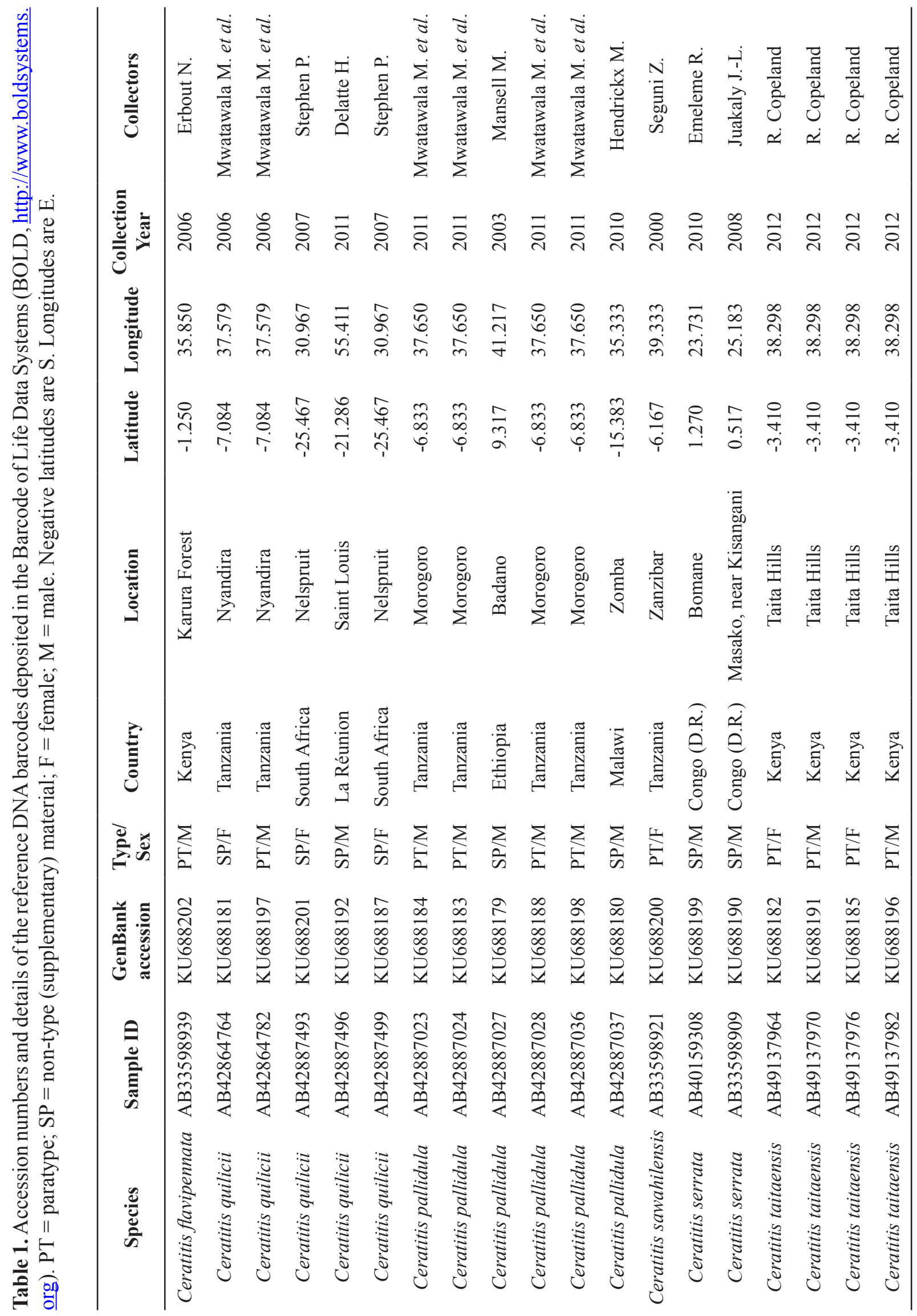



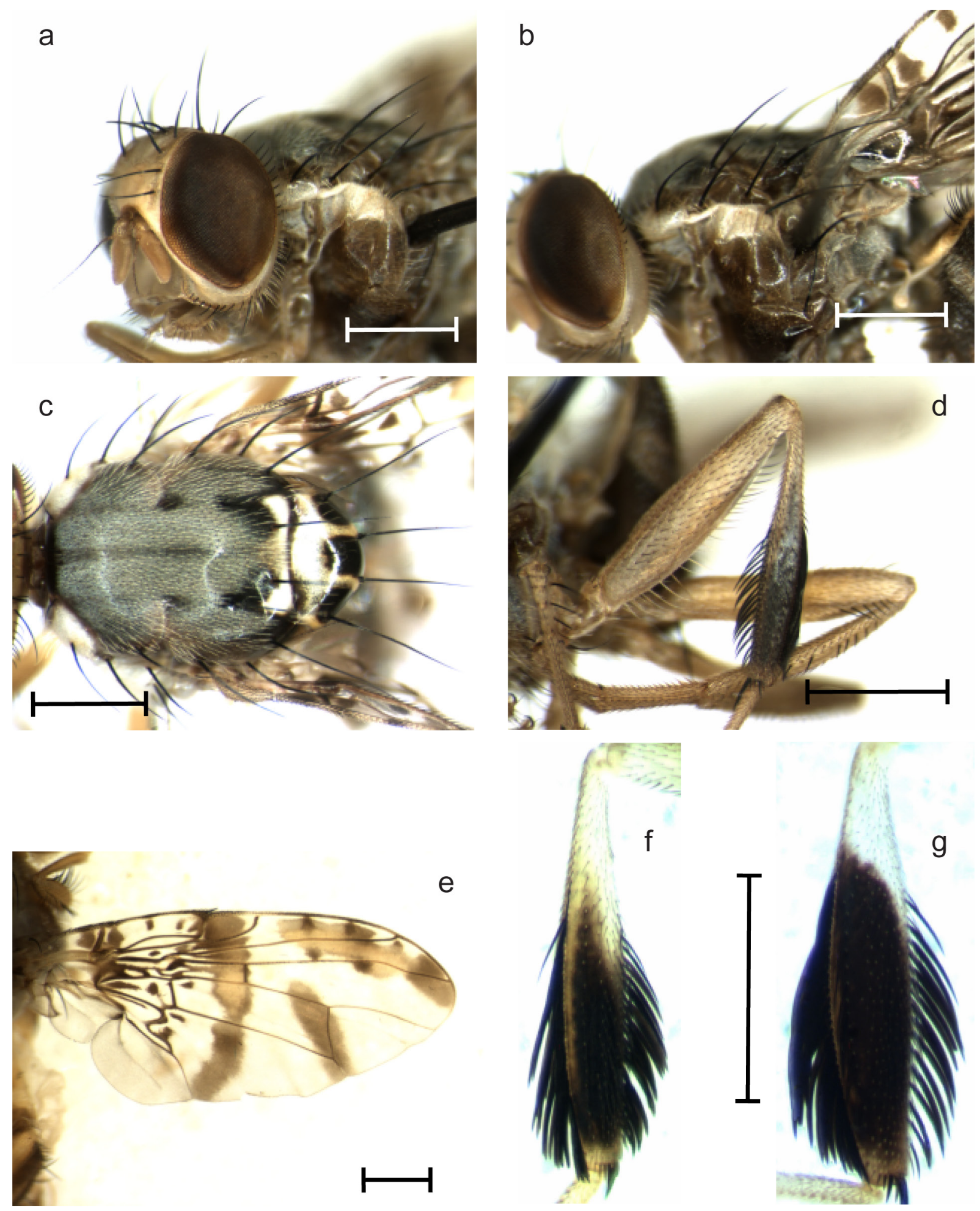

Fig. 1. - a-f. Ceratitis quilicii De Meyer, Mwatawala \& Virgilio sp. nov. $\widehat{O}$. a. Head and thorax, anterodorsal view. b. Head and thorax, lateral view. c. Thorax, dorsal view. d. Midleg, anterior view. e. Wing. f. Midtibia, anterior view. - g. C. rosa Karsch, 1887 s.str. midtibia, anterior view. Scale bars $=1 \mathrm{~mm}$. 
SWAZILAND: Ngonini Estates.

TANZANIA: Amani; Arusha Municipality; Kibundi; Kidiwa; Langali; Lushoto; Mikese; Mlali; Morogoro Municipality; Moshi Municipality; Mgeta Msikitini; Nyandira; Pinde; Tengeru; Visada.

ZIMBABWE: Harare; Vumba.

\section{Description}

Male

Body LENGTH. 4.81 (3.68-5.68) mm; wing length: 5.55 (4.48-6.08) mm.

HeAD (Fig. 1a). Antenna yellow. First flagellomere in lateral view 2-3 times as long as wide, obtuse apically. Arista short to medium pubescent, ventral proximal rays at most twice width of arista at base. Two frontal setae, thinner than, and subequal in length to, anterior orbital seta; two orbital setae, anterior orbital longer than posterior one; ocellar seta at least 4 times as long as ocellar triangle; postocellar seta black, shorter than lateral vertical seta. Frons convex, not protruding in lateral view, yellow to yellowish-white. Genal seta and setulae black. Face and occiput yellowish-white, the latter somewhat darker dorsally.

Thorax (Fig. 1b-c). Postpronotal lobe white to yellowish-white, without black middle spot around base of postpronotal seta. Scutum ground color greyish to greyish-brown, sometimes with orange tinge; with streaks and darker markings but without distinct spots except pair of separate prescutellar white markings, usually with pale yellowish-white area in between. Setae black. Anepisternum on ventral half darker yellowish-brown to brown; with pale pilosity, one anepisternal seta. Anatergite and katatergite white. Scutellum yellowish-white, usually with two narrow separate dark brown spots basally, sometimes less distinct; apically with three separate black spots, extending anteriorly to level of or just anterior to basal scutellar seta. Subscutellum black.

LEGS (Fig. 1d, f). Slender; yellow or yellowish-white except where otherwise noted; setation mixed pale and black. Forefemur with dispersed rows of long black setulae posterodorsally, posteroventrally shorter and pale; ventral spine-like setae black. Midfemur with few dispersed pale setulae ventrally; midtibia thin at base, moderately and gradually broadened; anteriorly black with conspicuous silvery shine when viewed from certain angle on distal 0.66 to 0.75 (black color sometimes inconspicuous in teneral specimens but silvery shine is always present), black color usually not reaching ventral and dorsal margins, especially on basal part; with black feathering dorsally along distal 0.75 and ventrally along distal 0.66 , occasionally to distal 0.75 . Hindfemur at distal 0.25 with longer setulae dorsally and ventrally.

WING (Fig. 1e). Markings yellowish-brown. Anterior apical band, subapical band and discal band present, posterior apical band absent; anterior apical band not touching discal band; subapical band isolated. Cross-vein R-M situated at or just before midlength of cell dm. Brown streaks and spots present in basal cells.

ABDomen. Ground colour mainly yellow. Tergites 2 and 4 on posterior half with greyish microtrichosity; anterior margin sometimes narrowly brownish colored, especially laterally. Tergite 3 with posterior half patchily brownish, anterior half yellowish-brown, both parts not clearly demarcated; sometimes more extensively brown. Tergite 5 with basal half brownish, sometimes divided medially by paler spot.

\section{Female}

Unknown (see remarks). 


\section{Distribution}

Based upon the above listing, C. quilicii sp. nov. is widely distributed throughout southern and eastern Africa with confirmed records from Botswana, Kenya, Malawi, South Africa, Swaziland, Tanzania and Zimbabwe. It is also known from Réunion Island.

\section{Host records}

The recent recognition that $C$. rosa s.lat. actually comprises two distinct species (see Remarks below) requires a re-examination of all material previously reported under ' $C$. rosa', including records on host use. Reared material that could be studied and identified confirmed the following plants as hosts for $C$. quilicii sp. nov.: Myrtaceae: Psidium cattleianum Sabine, P. guajava L., Syzygium jambos (L.) Alston; Rosaceae: Eriobotrya japonica (Thunb.) Lindley, Malus domestica Borkh., Prunus persica (L.) Batsch, Pyrus communis L., Rubus sp.; Rubiaceae: Coffea arabica L.; Sapotaceae: Chrysophyllum magalismontanum Sond., Englerophytum natalense (Sond.) T.D. Penn.

\section{Remarks}

Ceratitis quilicii sp. nov. belongs to the subgenus Pterandrus and in particular to the Pterandrus section A as defined by Barr \& Wiegmann (2009). Within this section, it belongs to the Ceratitis FAR complex as defined by Barr \& McPheron (2006) and Virgilio et al. (2008). A recent study by Virgilio et al. (2013) recognized five microsatellite genotypic clusters within the complex, two of which correspond with Ceratitis rosa. Further studies including morphometrics, developmental physiology, cuticular hydrocarbons, pheromones and mating incompatibility (De Meyer et al. 2015b and references therein) provided evidence that these two genotypic clusters represent two distinct entities that should be considered separate species. Mwatawala et al. (2015) furthermore presented evidence that the two entities appear to have different environmental requirements, a case that was supported by some of the differences observed by Tanga et al. (2015). These studies also confirmed the earlier proposed hypothesis by Grout \& Stoltz (2007) that C. rosa could actually include two separate entities with different ecological requirements. However, a study along an altitudinal transect in central Tanzania (Mwatawala et al. 2015), as well as re-examinations of material housed in natural history collections, have shown that the two species can co-occur in particular areas.

This species is largely identical to C. rosa. Only the males can be distinguished by minor differences of the midtibia, $C$. rosa having a broader midtibia with black coloration reaching the ventral and dorsal margins of the tibia throughout (Fig. 1g), while C. quilicii sp. nov. has a more slender tibia, gradually tapering towards the base, and with the black coloration not reaching the ventral and dorsal margins throughout the full length (Fig. 1f). Females cannot be differentiated currently and, therefore, no female specimens are included in the type series. The description of the female of C. rosa as given in De Meyer \& Freidberg (2006) applies to C. quilicii sp. nov. as well.

Ceratitis rosa has been referred to as "R1", "the hot type" or "lowland type" in previous literature regarding the two species, while C. quilicii sp. nov. has been referred to as "R2", "the cold type" or "highland type" (see De Meyer et al. 2015b and Hendrichs et al. 2015, and references therein). The DNA barcodes produced for five specimens of C. quilicii sp. nov. from Tanzania, South Africa and La Réunion (see Table 1 for voucher details and accessions) have a mean p-distance $=0.6 \%$ (Tamura et al. 2013). As already observed (Virgilio et al. 2008), DNA barcoding does not allow the unambiguous identification of species within the Ceratitis FAR complex. C. quilicii sp. nov. is no exception, as it clusters together with vouchers of $C$. rosa from Kenya and Mozambique (the morphological identification of these latter was verified and confirmed as C. rosa) (Supplementary file). 
Ceratitis (Ceratalaspis) pallidula De Meyer, Mwatawala \& Virgilio sp. nov. urn:Isid:zoobank.org:act:A06A2B1F-6C0F-4AB5-80AD-5216E863C6A8

Fig. 2

\section{Etymology}

After the Latin word 'pallidulus', meaning somewhat pale (as diminutive of pallidus). The species name should be treated as an adjective.

\section{Material examined}

Holotype

TANZANIA: $\widehat{0}$, Morogoro, Sokoine University of Agriculture, Horticulture Unit, EGOlure trap, T19570, 15 Jun. 2013, M. Mwatawala \& J. Kusolwa (RMCA).

Paratypes (deposited in RMCA, SUA, BMNH, SANC, and USNM)

TANZANIA: same locality as holotype: 16 $\widehat{\partial}, 1$ Jun. 2013, T19480; 14 $\widehat{\partial}, 1$ Jun. 2013, T19486;

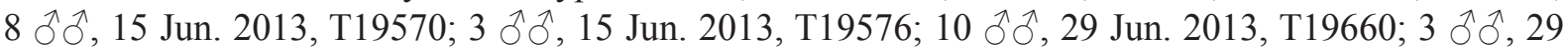

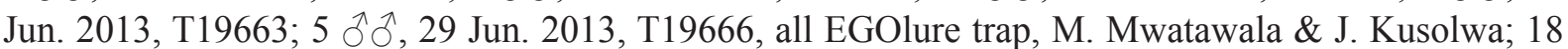

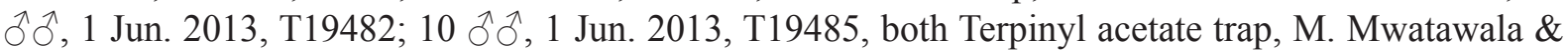

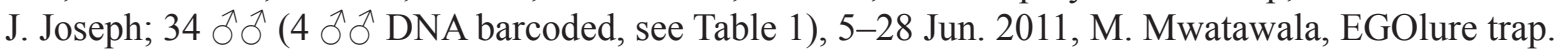

\section{Non-type material}

BURUNDI: $16 \curvearrowright ð$, Rumonge, 24 Jul.-11 Nov. 2013, terpinyl acetate trap, B. Nzigidahera (RMCA).

ETHIOPIA: $2 \precsim ð(1 \precsim$ DNA barcoded, see Table 1), Badano, Oct. 2010, terpinyl acetate trap, M. Mansell (RMCA).

MALAWI: $2 \precsim \widehat{\partial}(1 \precsim$ DNA barcoded, see Table 1), Zomba, 31 Oct. 2010-7 Mar. 2011, EGOlure trap, M. Hendrickx (RMCA).

TANZANIA: 1 đ̊, Kimani, RtA104, 29 Aug. 1996, A. Freidberg (TAU).

\section{Description}

Male

Body LENGTH. 3.0 (2.72-3.36); wing length: 3.10 (2.80-3.36) mm.

HEAD (Fig. 2a). Antenna yellow, first flagellomere in lateral view twice as long as wide; with short acute tip apically. Arista short pubescent, ventral proximal rays at most equal to width of arista at base. Two frontal setae, thinner than, and subequal in length to, anterior orbital seta; two orbital setae, anterior orbital longer than posterior one; ocellar seta about 3 times as long as ocellar triangle; postocellar seta black, shorter than lateral vertical seta. Frons convex, not protruding in lateral view; yellow-white. Genal seta pale, genal setulae mixed yellow and dark. Face and occiput white.

Thorax (Fig. 2b-c). Postpronotal lobe yellowish-white, without black middle spot around base of postpronotal seta. Scutum ground colour shining pale yellow to yellow-orange, with pale pilosity/ microtrichosity; distinct paired black spot situated between dorsocentral and prescutellar acrostichal setae, (almost) touching, but not engulfing prescutellar acrostichal seta, posteriorly with prescutellar white semi-circular or similar marking; indistinct to distinct black spot near mesal end of transverse suture; occasionally additional black medial spot at level of transverse suture; lateral margins of scutum with black spots reduced, only paired spot on posterior lateral corner well developed. Setae black, except scapulars white. Pleura yellow-white. Anepisternum dorsal margin narrowly white, ventral 
half sometimes darker yellow, one anepisternal seta. Anatergite white, rarely with irregular black spot. Scutellum yellowish-white, apical margin with three large separate black spots, anteriorly extending to level of basal scutellar setae; with two brown to blackish, round submedial spots basally. Subscutellum black, sometimes more yellow submedially on ventral part.

a
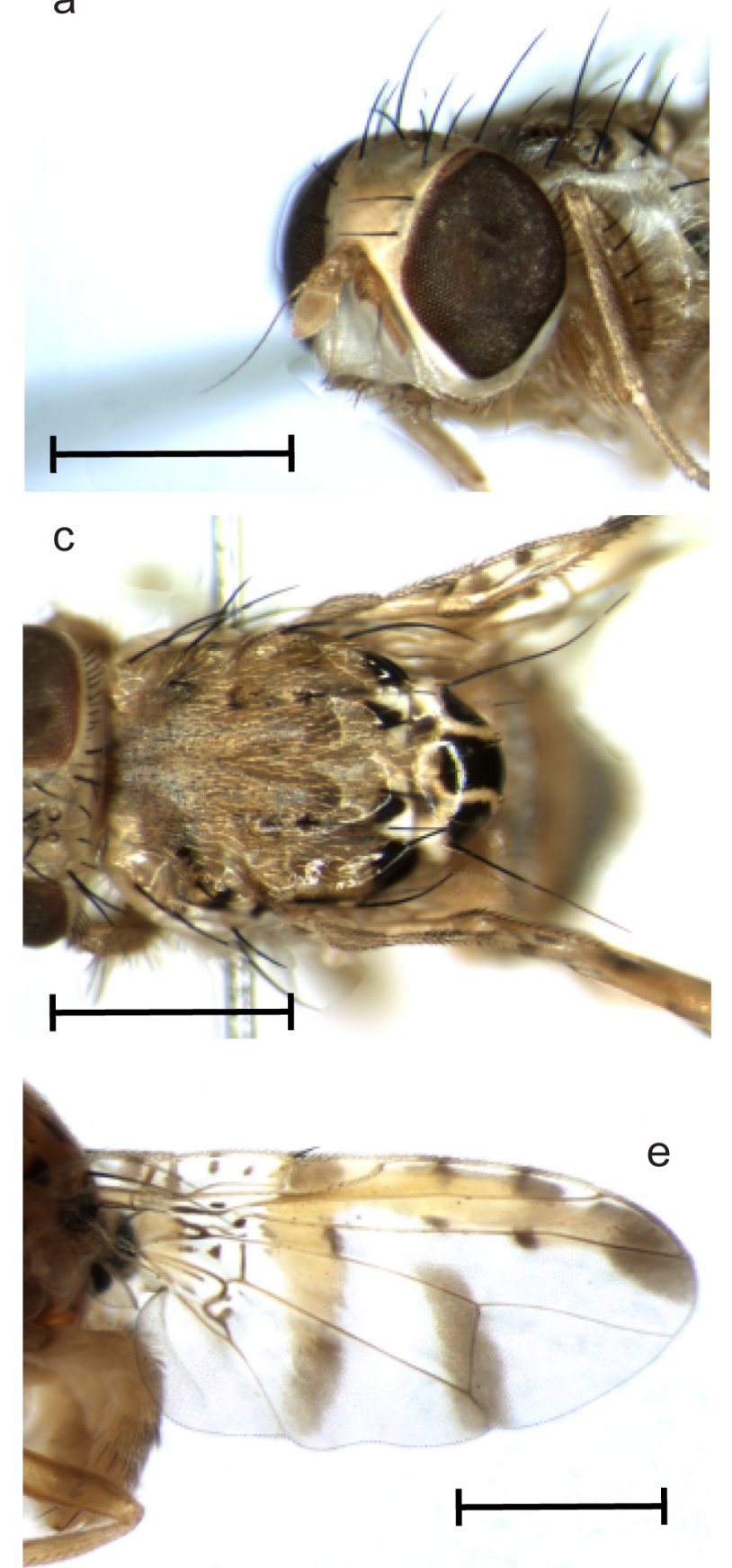

b
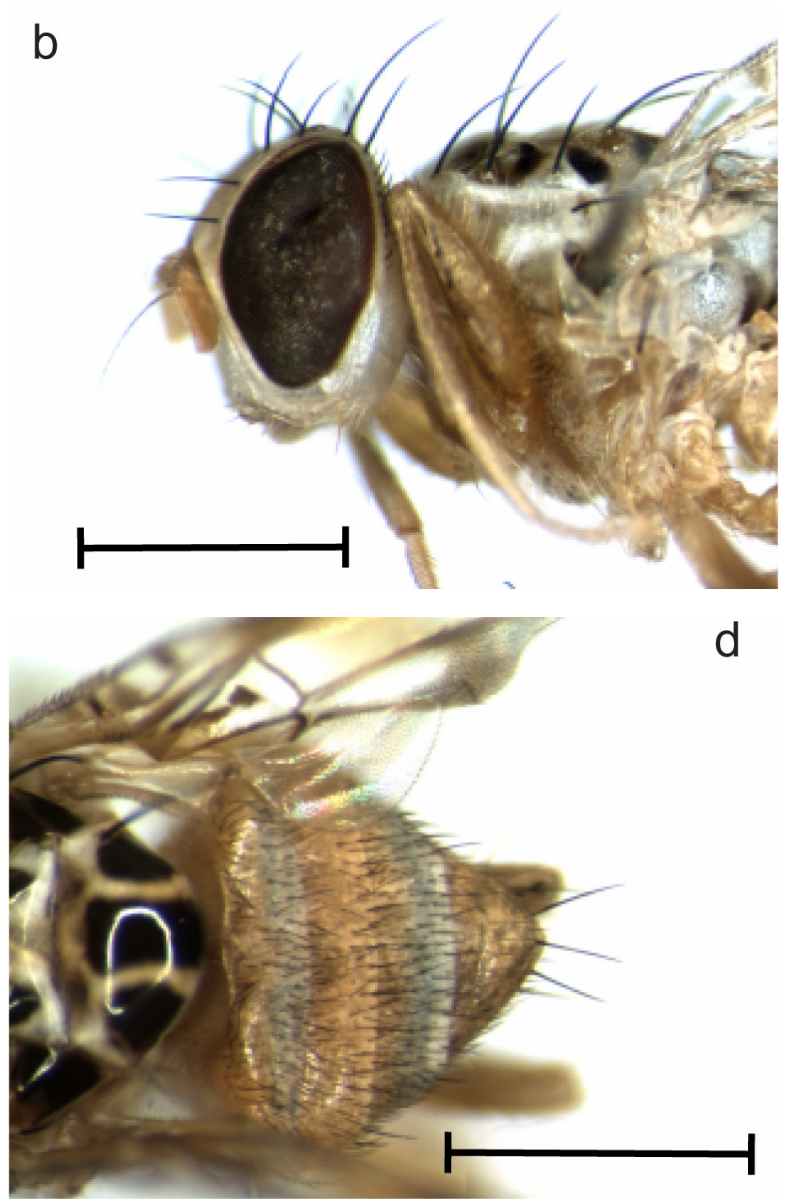

Fig. 2. Ceratitis pallidula De Meyer, Mwatawala \& Virgilio sp. nov. a. Head and thorax, anterodorsal view. b. Head and thorax, lateral view. c. Thorax, dorsal view. d. Abdomen, dorsal view. e. Wing. Scale bars $=1 \mathrm{~mm}$. 
LEGS. Slender; yellow; with dispersed pale pilosity. Forefemur with pale ventral spine-like setae.

WING (Fig. 2e). Markings yellow to yellowish-brown. Anterior apical band, subapical band and discal band present, posterior apical band absent; anterior apical band touching discal band; subapical band isolated. Cross-vein R-M at about basal third of cell $\mathrm{dm}$. Brown streaks and spots present in basal cells.

ABdomen (Fig. 2d). Ground colour yellow to orange; setulae and setae dark brown. Tergites 2 and 4 on posterior half to two-thirds with greyish microtrichosity.

\section{Female}

Unknown.

\section{Distribution}

Burundi, Ethiopia, Tanzania, Malawi.

\section{Host plants}

Unknown.

\section{Remarks}

While this species was until recently unknown, it has been found in relatively high numbers (up to $400 \mathrm{flies} /$ trap/week) through trapping activities using enriched ginger oil (EGOlure, Insect Science, Tzaneen South Africa) in central Tanzania (Mwatawala et al. 2013; referred to as ' $C$. near cosyra'). The first identification placed this as small specimens of C. cosyra (Walker, 1849) but the morphological differences in mesonotal pattern and genetic differentiation of DNA barcodes (Table 1; Supplementary file) indicated this was not the case. Afterwards, additional specimens were trapped in other countries and it appears to be present throughout a wide range. The species is similar to C. cosyra but can be readily differentiated by the absence of a black spot on the postpronotal lobe and the much smaller size. It also resembles $C$. quinaria (Bezzi, 1918) and C. silvestrii Bezzi, 1912 in general appearance but can be differentiated from the former by the three apical spots on the scutellum (five spots in C. quinaria) and from both by the presence of a black spot near the prescutellar acrostichal seta (absent in both C. quinaria and C. silvestrii).

Ceratitis (Ceratalaspis) taitaensis De Meyer \& Copeland sp. nov. urn:1sid:zoobank.org:act:1BFD784E-BA50-4D89-899A-707DD7D6A3B6

Fig. 3

\section{Etymology}

The name is considered as an adjective derived from the geographical name 'Taita' referring to the Taita Hills, located in southeastern Kenya. The Taita Hills are the northernmost block of the Eastern Arc Mountain chain.

\section{Material examined}

\section{Holotype}

KENYA: $\widehat{\jmath}$, Vuria, reared from fruits of Lepidotrichilia volkensii, 16 May 2012, R.S. Copeland (NMK) (CHIESA coll. Nr 228).

Paratypes (deposited in NMK, ICIPE, RMCA, BMNH, and NMNH)

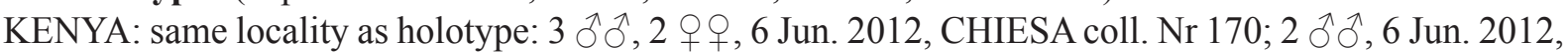

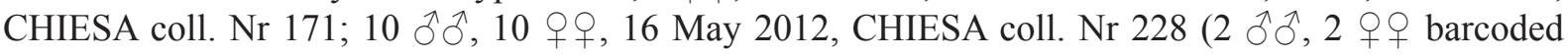



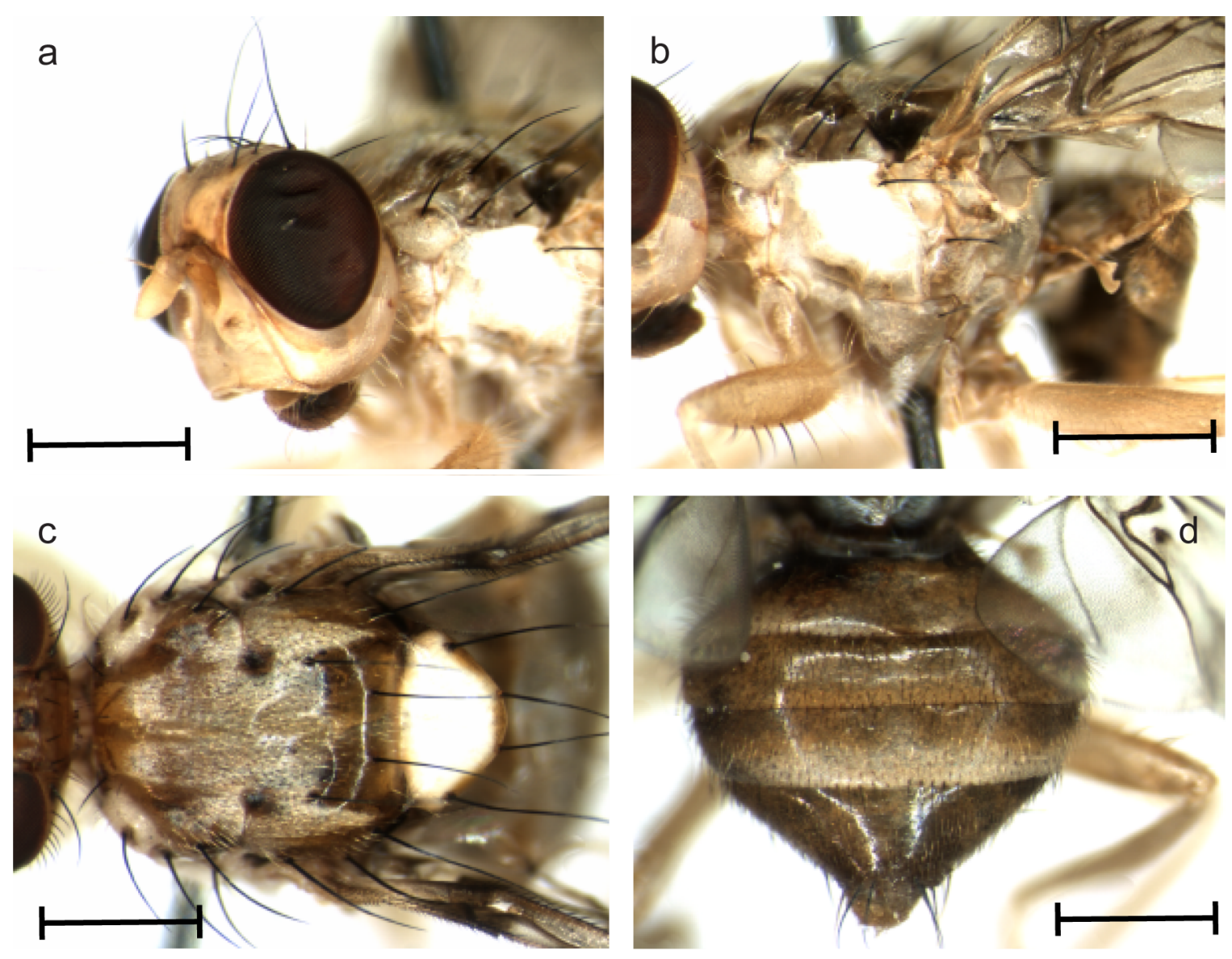

e
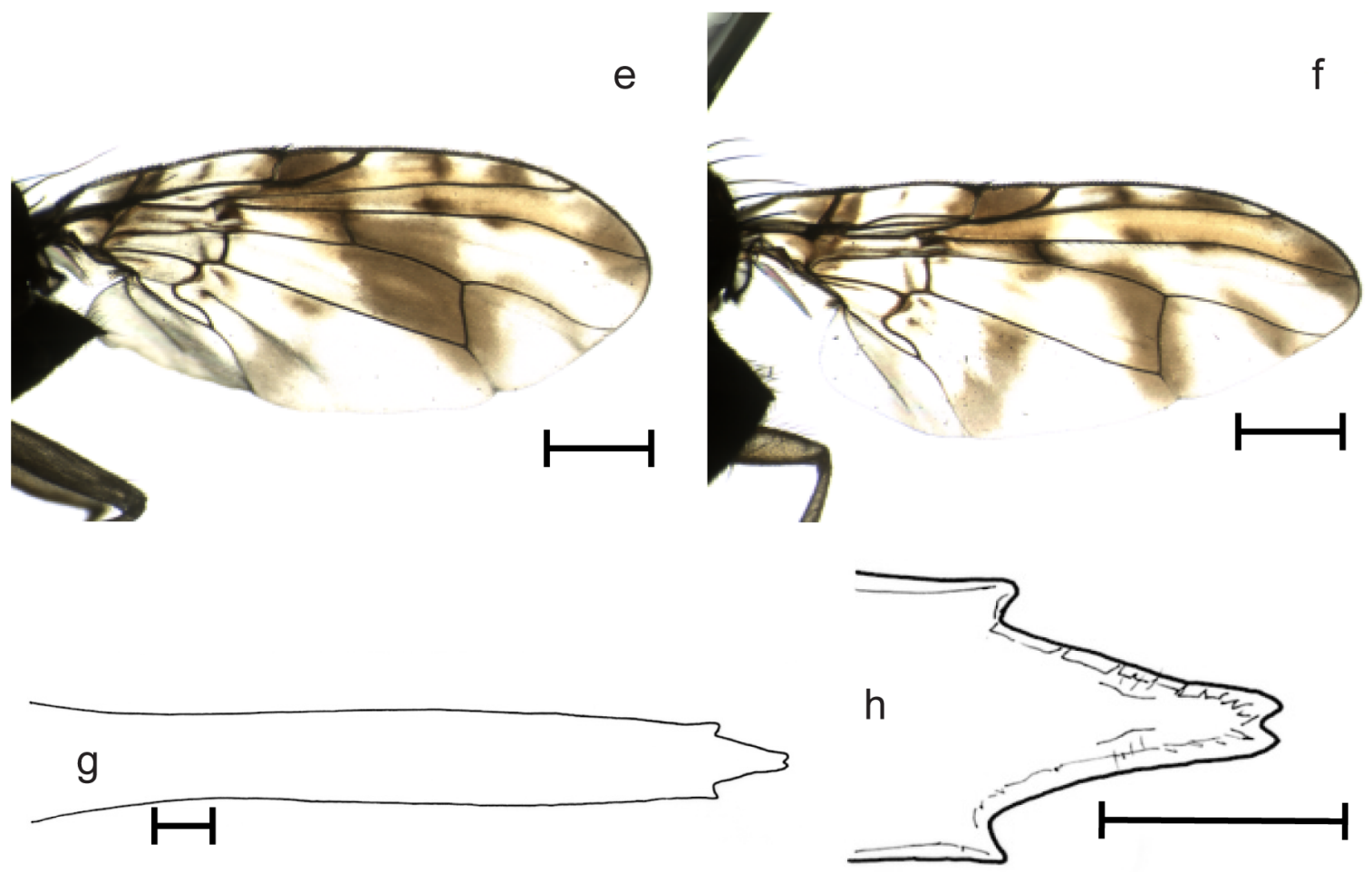

Fig. 3. Ceratitis taitaensis De Meyer \& Copeland sp. nov. a. Head and thorax, anterodorsal view. b. Thorax, lateral view. c. Thorax, dorsal view. d. Abdomen, dorsal view. e. Male wing. f. Female wing. g. Female aculeus. h. Aculeus tip. Scale bars: $A-F=1 \mathrm{~mm} ; \mathrm{G}-\mathrm{H}=0.1 \mathrm{~mm}$. 


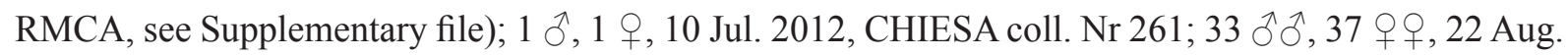
2012, CHIESA coll. Nr 269, all R.S. Copeland, reared from Lepidotrichilia volkensii (Gürke) Leroy.

\section{Description}

\section{Male}

BoDy LENGTH. 5.61 (5.04-6.08) mm; wing length: $6.20(5.68-6.88) \mathrm{mm}$.

HEAD (Fig. 3a). Antenna yellow. First flagellomere in lateral view twice as long as wide; obtuse apically. Arista short to medium pubescent, ventral proximal rays at most twice width of arista at base. One frontal seta, thinner than, and subequal in length to, anterior orbital seta; two orbital setae, anterior seta longer than posterior one; ocellar seta about 3-4 times as long as ocellar triangle; postocellar seta black, shorter than lateral vertical seta. Frons convex, not protruding in lateral view; yellow to orange, with greyish microtrichosity on posterior half. Gena broader than in other Ceratitis species (maximum diameter of eye versus height of gena 2.5-3.0), genal seta and genal setulae yellow, latter sometimes blackish.

Thorax (Fig. 3b-c). Postpronotal lobe yellowish-white to white; with black middle spot around base of postpronotal seta. Scutum ground colour shining yellow-brown to dark brown, with silvery microtrichosity covering most of dorsum, except circular area posterior to mesal end of transverse suture and in trapezoid area extending posteriorly from dorsocentral setae to anterior margin of scutellum, and narrowly along lateral margins; sublaterally the microtrichosity extends posteriorly to the intralar seta; narrow area along anterior margin, extending posteriorly along midline and posterior of postpronotal lobe, with less dense microtrichosity. Anepisternum yellowish-white, lower margin darker; with pale pilosity, one anepisternal seta. Scutellum yellowish-white, with three yellow-brown spots restricted to apical margin and ventral side; area between spots darker yellowish coloured. Subscutellum entirely brown to black.

LEGS. Slender; yellow to yellowish-orange, tarsi sometimes slightly paler than rest of leg; with dispersed pale pilosity. Forefemur with dark brown ventral spine-like setae. Hindfemur at distal 0.25 with dark brown setae dorsally.

WING (Fig. 3e). Markings brownish to yellowish-brown. Of typical bands, only anterior apical band distinct, including pterostigma and area posterior of pterostigma to vein $\mathrm{R} 4+5$; furthermore with brownish spot covering area surrounding cross-vein R-M (i.e., apical margin of cell br) and basal third of cell $\mathrm{r} 4+5$, continued in apical half of cell $\mathrm{dm}$ and anterior third of cell $\mathrm{m}$, also broadly fused with anterior apical band; additional small marks in middle of cell $\mathrm{cu}_{1}$ and basal part of cell $\mathrm{m}$. Cross-vein $\mathrm{R}-\mathrm{M}$ at or just beyond midlength of cell $\mathrm{dm}$. Brown streaks and spots present in basal cells but poorly developed.

ABdomen (Fig. 3d). Ground colour yellow to orange-brown. Tergites 2 and 4 on posterior half to twothirds with greyish microtrichosity.

\section{Female}

As male except for the following characters: gena less broad (maximum eye diameter to gena height ratio less than 2.5). Wing with well developed bands as in other Ceratitis species (Fig. 3f): discal band interrupted in cell $\mathrm{dm}$; anterior apical band and discal band separated or only narrowly touching; subapical band narrowly touching anterior part of discal band; posterior apical band isolated. Oviscape orange, with dispersed dark brown to black pilosity. Tergal-oviscapal ratio (= length of abdominal tergites $1-5$ versus length of oviscape): 1.5-2. Aculeus (Fig. 3g-h) flattened, 7-8 times longer than broad, apex bifurcated, and with pair of subapical protuberances. 


\section{Distribution}

Kenya.

\section{Host plants}

Reared from fruits of Lepidotrichilia volkensii (Gürke) Leroy (Meliaceae).

\section{Remarks}

Ceratitis whartoni was described by De Meyer \& Copeland (2009) from forested areas in the Central Highlands of Kenya (Gatamayu Forest, Nyanduma Forest, Mt. Kenya Forest), all reared from fruits of Lepidotrichilia volkensii (Meliaceae). It was an enigmatic species because of the dimorphic wing pattern, with that of the male largely differing from the standard wing banding found in most other Ceratitis species. A series of specimens reared from the same host plant collected in Taita Hills (approximately 400 $\mathrm{km}$ southeast of the nearest site of $C$. whartoni) are morphologically almost identical, with only slight differences in wing pattern and female aculeus (male wing with dark marking in cell dm occupying more than half of cell in C. whartoni, less than half in C. taitaensis sp. nov.; female wing with discal band complete in $C$. whartoni, partially interrupted in cell $\mathrm{dm}$ in $C$. taitaensis sp. nov.; aculeus with bifurcated apex more slender in $C$. taitaensis sp. nov. (less than one-third of entire width) and invagination less deep than in C. whartoni). However, the analysis of the available DNA barcodes of C. whartoni (Table 1; Supplementary file) revealed remarkable genetic differentiation from C. taitaensis sp. nov. (p-distance $=8.5 \%$ ). It was, therefore, decided to recognize this as a separate species. The Taita Hills are a chain of forested mountain tops surrounded by the flat and dry Tsavo Plains. They form the northernmost mountainous massif of the Eastern Arc Mountains, a chain of ancient crystalline mountains (Burgess et al. 2007) and are considered a major biodiversity hotspot (Meyers et al. 2000). We place this species in the subgenus Ceratalaspis for the same reasons as outlined in De Meyer \& Copeland (2009) regarding the placement of $C$. whartoni.

Ceratitis (Ceratalaspis) sawahilensis De Meyer \& Virgilio sp. nov. urn:Isid:zoobank.org:act:F57EF53D-53E8-4EBF-A268-8FB819DBEEB4

Fig. 4

\section{Etymology}

The name is considered as an adjective derived from a geographical name, the Arabic word 'sawahil' being the plural of 'sahil', which means border or coast and refers to the Swahili Coast, which was recognized as a historical cultural and geographic entity comprising the localities of Zanzibar and Mkuranga, where the type series was collected.

\section{Material examined}

\section{Holotype}

TANZANIA: §̂, Mkuranga, Mwanambaya, 21 Jan. 2001, Z. Seguni (RMCA).

\section{Paratypes}

TANZANIA: $1 \hat{\jmath}$, same date and locality as holotype; $1 \hat{\jmath}, 1$ ㅇ, Zanzibar, 7 Feb. 2000, Z. Seguni (1 q barcoded, see Table 1; Supplementary file), (RMCA); 1 ô (Fig. 4f), Magombero Forest, 14-15 Sep. 2009, T. Pape \& S.A. Marshall (ZMUC).

\section{Description}

\section{Male}

Body LeNGTH. 5.01 (4.80-5.28); wing length: 5.04 (4.80-5.20) mm. 

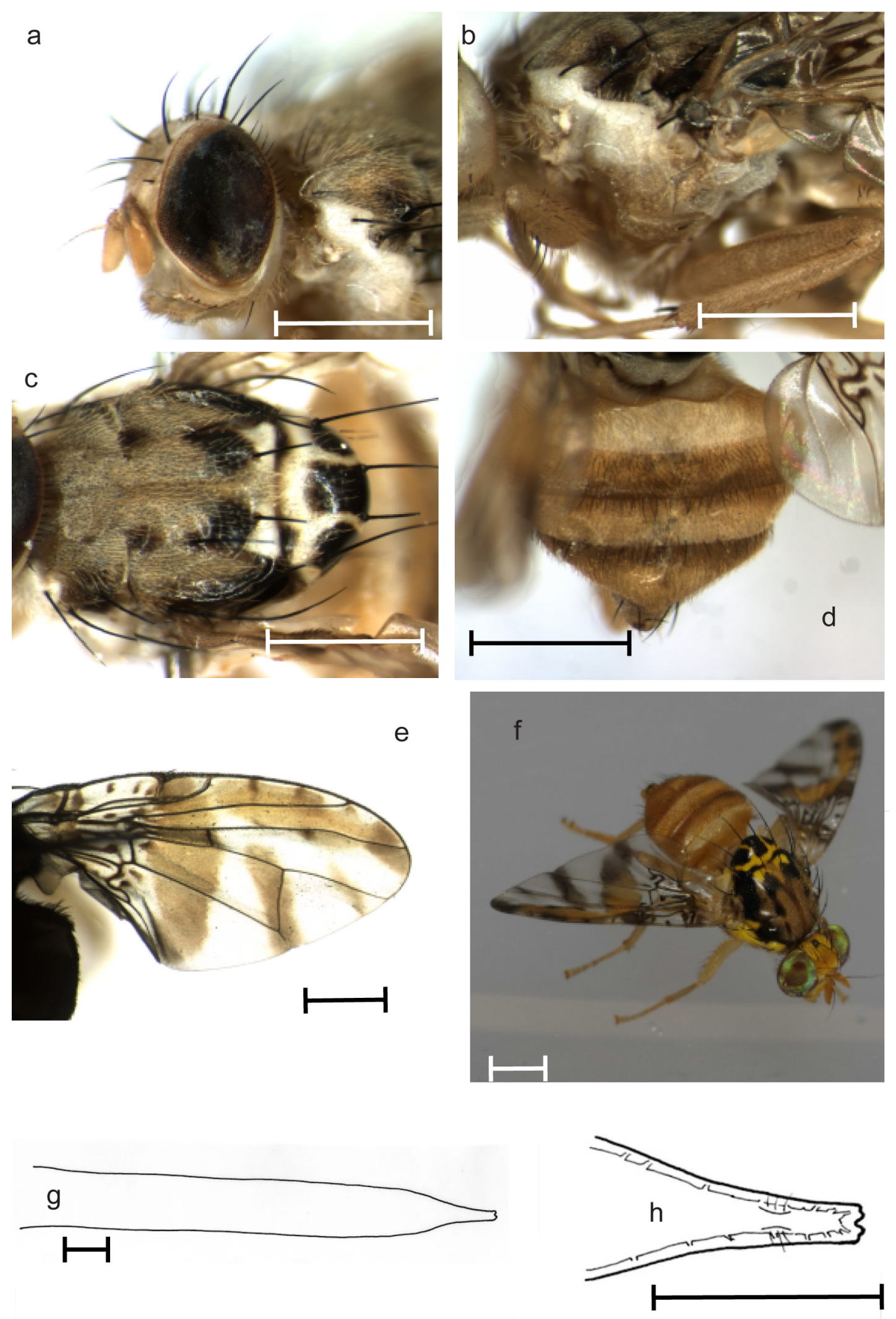

Fig. 4. Ceratitis sawahilensis De Meyer \& Virgilio sp. nov. a. Head and thorax, anterodorsal view. b. Thorax, lateral view. c. Thorax, dorsal view. d. Abdomen, dorsal view. e. Wing. f. Habitus image (credit: S.A. Marshall). g. Female aculeus. h. Aculeus tip. Scale bars: A-F $=1 \mathrm{~mm} ; \mathrm{G}-\mathrm{H}=0.1 \mathrm{~mm}$. 
HEAD (Fig. 4a). Antenna yellow-orange, first flagellomere in lateral view 3 times as long as wide, obtuse or with short acute tip dorsoapically. Arista medium pubescent, ventral proximal rays at most 3 times width of arista at base. Two frontal setae, thinner than, and subequal in length to, anterior orbital seta; two orbital setae, anterior orbital longer than posterior one; ocellar seta at least 4 times as long as ocellar triangle; postocellar seta black, shorter than lateral vertical seta. Frons convex, not protruding in lateral view; yellow-white, in between frontal setae more yellowish. Genal seta and genal setulae dark brown to reddish-pale. Face and occiput yellowish-white, latter slightly darker dorsally.

Thorax (Fig. 4b-c). Postpronotal lobe white, without black middle spot around base of postpronotal seta. Scutum ground colour shining yellow-brown to brown, sometimes with more orange tinge, with greyish pilosity and microtrichosity; with slightly darker streaks but no distinct black spots, except paired prescutellar spot extending anteriorly to dorsocentral seta, posteriorly with paired white to yellow prescutellar semi-circular marking, separated by yellowish-white area in between; at mesal end of transverse suture with shining brownish to blackish spot. Setae black. Pleura yellow to brownishyellow. Anepisternum dorsal half white, ventral half yellow; completely covered with pale pilosity, one anepisternal seta. Anatergite and katatergite white. Scutellum yellowish-white to white, sometimes with yellowish tinge; apical margin with three separate black spots, extending to level of basal scutellar setae; with distinct brown-black spots basally, sometimes less pronounced and only darker yellowbrown colour. Subscutellum black.

LeGs. Slender; yellow; with dispersed mixed pale and dark pilosity. Forefemur ventral spine-like setae black along distal 0.50 , basally more pale.

WING (Fig. 4e). Markings yellow to yellow-brown. Anterior apical band, subapical band, discal band and posterior apical band present, latter sometimes only as a trace; anterior apical band touching discal band; subapical band and posterior apical band isolated. Cross-vein R-M situated at or basal to midlength of anterior margin of cell $\mathrm{dm}$. Brown streaks and spots present in basal cells.

AвDOMEn (Fig. 4d). Ground colour yellow. Tergites 2 and 4 more greyish along posterior half; tergites 3 and 5 with, respectively, posterior and anterior margin narrowly more darkly yellow. With mixed pale and dark pilosity.

\section{Female}

As male. Oviscape shorter than preabdomen. Aculeus (Fig. 4g-h) about 8-9 times longer than wide; apical part sinuous, tip blunt and with distinct indentation.

\section{Distribution}

Tanzania.

\section{Host plants}

Unknown.

\section{Remarks}

The relationship of C. sawahilensis sp. nov. to any of the other described Ceratitis species is not easily established. Although there is a slight partial darkening of the abdominal tergites 3 and 5, the male legs are without modifications. The neighbor-joining tree (Supplementary file) does not place it in any resolved cluster. We tentatively place it in the subgenus Ceratalaspis pending further clarifications on its subgeneric position. 
Ceratitis (Ceratalaspis) flavipennata De Meyer \& Virgilio sp. nov. urn:Isid:zoobank.org:act:72C8DD57-0FD1-4B48-96FA-881BFDDBA205

Fig. 5

\section{Etymology}

After the Latin 'flavus' meaning yellow and 'pennatus' meaning feathered, and referring to the yellow feathering on the midtibia. The species name should be treated as an adjective.

\section{Material examined}

Holotype

KENYA: ${ }^{\lambda}$, Karura Forest, 11 Aug. 2006, N. Erbout (RMCA).

\section{Paratype}

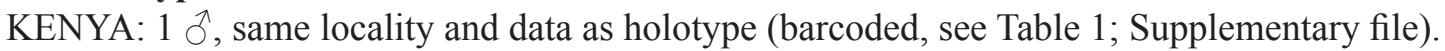

\section{Description}

\section{Male}

Body LENGTH. 4.08 (3.92-4.16) mm; wing length: 4.88 (4.80-4.96) mm.

HEAD (Fig. 5a). Antenna yellow, first flagellomere in lateral view 3 times as long as wide, obtuse apically. Arista short to medium pubescent, ventral proximal rays at most twice width of arista at base. Two frontal setae, thinner than, and subequal in length to, anterior orbital seta; two orbital setae, anterior orbital longer than posterior one; ocellar seta about 3 times as long as ocellar triangle; postocellar seta black, shorter than lateral vertical seta. Frons convex, not protruding in lateral view; yellow. Genal seta and genal setulae pale to dark orange. Face yellow-white, occiput yellow.

THORAX (Fig. 5b-c). Postpronotal lobe yellow-orange, slightly paler than scutum; without distinct black middle spot around base of postpronotal seta but with darker irregular marking near seta. Scutum ground colour shining orange to orange-brown, with pale pilosity/microtrichosity; with distinct small black spot near mesal end of transverse suture; otherwise no distinct black marking on central part of scutum; paired separate prescutellar semi-circular white markings posterior of prescutellar acrostichal seta. Setae black, except scapulars red brown. Pleura yellow-orange to yellow-brown. Anepisternum dorsal margin narrowly white, ventral third to half more brownish; one anepisternal seta. Anatergite yellow-white, with irregular black marking; katatergite yellow-white. Scutellum yellowish-white, apical margin with three separate black spots, extending anteriorly beyond basal scutellar seta; without distinct black spots basally, at most with slightly darker marking. Subscutellum yellow with three black spots of which the upper margin is confluent, thereby forming single black band.

Legs (Fig. 5e). Slender; yellow to yellow-orange; with dispersed yellow-orange pilosity. Forefemur with orange ventral spine-like setae, posterodorsally and posteriorly with several rows of longer yelloworange setae, producing bushy appearance. Midtibia with yellow-orange feathering dorsally along distal 0.45 and ventrally along distal 0.30 .

Wing (Fig. 5f). Markings yellow to yellow-brown. Anterior apical band, subapical band, posterior apical band and discal band present; anterior apical band not touching discal band; subapical band touching discal band; posterior apical band touching anterior apical band. Cross-vein R-M situated just beyond midlength of cell $\mathrm{dm}$. Brown streaks and spots present in basal cells.

ABdomen (Fig. 5d). Ground colour yellow to orange, pale and brown setulae. Tergites 2 and 4 along posterior margin slightly more greyish. 
Female

Unknown.

\section{Distribution}

Kenya.
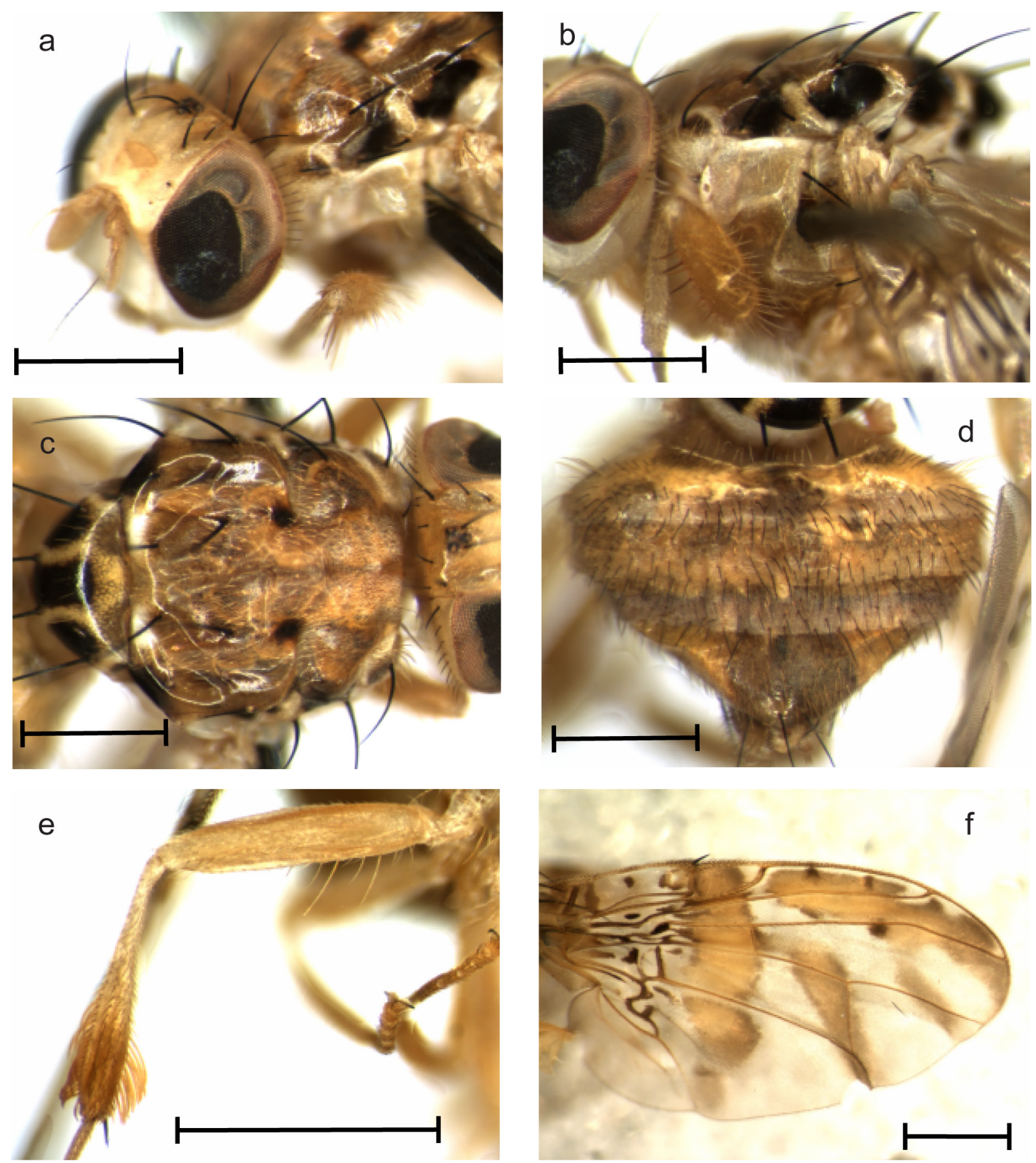

Fig. 5. Ceratitis flavipennata De Meyer \& Virgilio sp. nov. a. Head and thorax, anterodorsal view. b. Thorax, lateral view. c. Thorax, dorsal view. d. Abdomen, dorsal view. E. Midleg, anterior view. F. Wing. Scale bars $=1 \mathrm{~mm}$ 


\title{
Host plants
}

Unknown.

\section{Remarks}

Ceratitis flavipennata sp. nov. resembles Ceratitis neostictica De Meyer, 1998 in the pilosity of the forefemur and feathering on the midtibia. It can be differentiated from the latter by the differences in wing banding (posterior apical band touching anterior apical band in flavipennata sp. nov., separate in neostictica; subapical band touching discal band in flavipennata sp. nov., separate in neostictica) and the pattern of the scutum (extensive black markings in neostictica, largely absent in flavipennata sp. nov.). Like C. neostictica, C. Alavipennata sp. nov. is placed in the subgenus Ceratalaspis based on the colouration of the abdominal tergites (predominantly yellow to orange, no distinct black transverse bands). Based on its DNA barcode it does not cluster with any other species within the genus Ceratitis (see Supplementary file).

Ceratitis (Pardalaspis) serrata De Meyer, 1996

Fig. 6

\author{
Material examined \\ Holotype \\ DEMOCRATIC REPUBLIC OF CONGO: + , Yangambi, 17 Nov. 1960, J.M. McGough (TAU).
}

\section{Non type material}

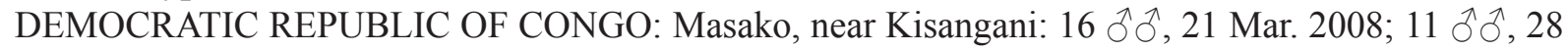

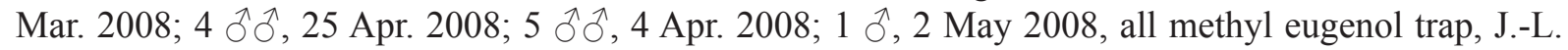
Juakaly (RMCA); 1 +, Congo River Expedition, Bomane, 19-24 May 2010, cue lure trap, R. Emeleme \& M. Virgilio (RMCA).

\section{Description}

\section{Male}

HeAd (Fig. 6a-b). Antenna orange. First flagellomere in lateral view 2-3 times as long as wide, obtuse apically. Arista short pubescent, ventral proximal rays at most equal to width of arista at base. Two frontal setae, thinner than, and equal in length, to anterior orbital seta; two orbital setae, anterior orbital longer than posterior one; ocellar seta 3-4 times as long as ocellar triangle; postocellar seta black, shorter than lateral vertical seta. Frons flattened, slightly protruding in lateral view, completely covered with silvery shine. Genal seta and setulae black. Face orange, occiput yellowish.

Thorax (Fig. 6c-d). Postpronotal lobe greyish to greyish-yellow, without black middle spot around base of postpronotal seta. Scutum ground color greyish-brown, sometimes with golden orange tinge; with streaks and darker markings but without distinct spots except for darkish spot around prescutellar acrostichal seta, and pale prescutellar semi-circular marking along posterior margin near prescutellar acrostichal seta. Setae black; setulae mainly pale; black setulae restricted to area at mesal end of tranverse suture extending posteriorly to prescutellar acrostical and dorsocentral setae. Anepisternum ventral half brownish, dorsal half more greyish, completely covered with black pilosity, except for horizontal stripe below dorsal margin with white pilosity; three anepisternal setae. Anatergite and katatergite brownish. Scutellum dark yellowish, apical margin with three separate black spots, anteriorly extending anteriorly beyond basal scutellar setae; with two large roundish black spots basally. Subscutellum black.

LEGs. Slender; yellow-orange, midfemur more brownish; with dispersed and mainly black pilosity. Forefemur with ventral setae black. 
WING. Markings dark brown. Anterior apical band, subapical band and discal band present, posterior apical band absent; anterior apical band touching discal band; subapical band isolated. Cross-vein R-M situated at midlength of cell $\mathrm{dm}$. Brown streaks and spots present in basal cells.

AвDOMEN (Fig. 6e). Ground colour mainly greyish to pale orange; with darker spots on all tergites. With mixed pale and black pilosity.
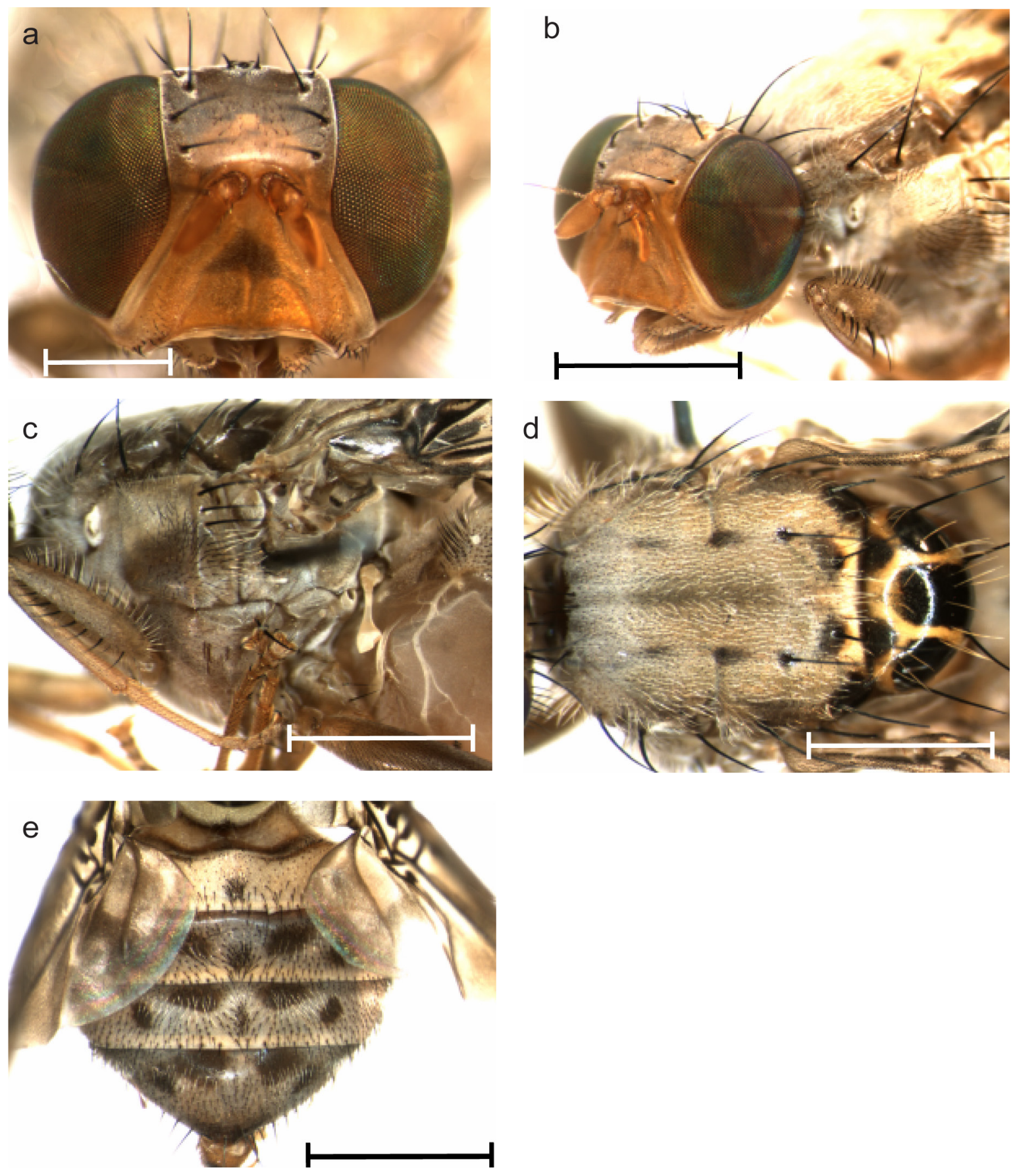

Fig. 6. Ceratitis serrata De Meyer, 1996. a. Head, frontal view. b. Head and thorax, anterodorsal view. c. Thorax, lateral view. d. Thorax, dorsal view. e. Abdomen, dorsal view. Scale bars: A $=0.5 \mathrm{~mm}$; $\mathrm{B}-\mathrm{D}=$ $1 \mathrm{~mm}$. 


\section{Distribution \\ Congo (Democratic Republic).}

\section{Host plants}

Unknown.

\section{Remarks}

Ceratitis serrata was originally described from a female collected in Yangambi in the Democratic Republic of Congo. Trapping with methyl eugenol at Masako (near Kisangani and approx. $100 \mathrm{~km}$ east of Yangambi) in 2008 collected male specimens that did not match any of the known species within the subgenus Pardalaspis. Virgilio et al. (2011) reported a female specimen of C. serrata from Bomane along the Congo River, further west of Yangambi. DNA barcoding revealed that the COI sequences obtained from the male specimen from Masako (series of 21.III.2008 AccessID 13954, AB33598909) and the female specimen from Bomane (AccessID 15755, AB40159308) differed by a p-distance of only $0.5 \%$ (see Table 1 ; Supplementary file) with a large barcoding gap (corresponding to $7 \%$ similarity) separating $C$. serrata from the second closest match. It was therefore considered that the material from Masako represents the hitherto unknown male of $C$. serrata. Male specimens of $C$. serrata can be readily differentiated from other species within the subgenus Pardalaspis by the combination of the following characters: frons completely silvery shining; face uniform orange coloured; anterior margin of scutum same colour as middle part; anepisternum largely covered with black pilosity, base of scutellum with a pair of distinct black spots.

\section{Discussion}

As indicated earlier, the taxonomy of the different subgenera within the genus Ceratitis has been revised in the last two decades (De Meyer 1996, 1998, 2000; De Meyer \& Copeland 2001; De Meyer $\&$ Freidberg 2006). For the most part, these revisions were based on material already deposited in different collections. However, because of more intensive surveying activities in different parts of Africa, additional undescribed species were encountered, and some have already been described (De Meyer \& Copeland 2005, 2009). Moreover, the multidisciplinary approach used in integrative taxonomy revealed the presence of cryptic species (see De Meyer et al. 2015a for a recent treatise of this in tephritid fruit flies). In groups of economic significance, such as Tephritidae, a proper identification is not only a prerequisite for any further research, be it fundamental or applied, but can also have serious political and economic consequences in aspects like control programs, quarantine regulations, and trade barriers (Hendrichs et al. 2015). Taxonomic recognition, preferably through different independent approaches, is a necessity and may facilitate accurate recognition of biological species (Clarke \& Schutze 2014). The description of Ceratitis quilicii sp. nov. in this paper is a case in point. Additional alpha taxonomic descriptions such as these contribute to the general knowledge of the group, and will allow more accurate identifications. It is, however, a requisite that the newly acquired information is also transferred to proper identification and reference tools such as DNA sequence libraries like BOLD or identification tools such as those presented by Virgilio et al. (2014).

\section{Acknowledgments}

The authors acknowledge the financial support by the following funding agencies and projects: the Belgian Development Cooperation through the framework program of the Royal Museum for Central Africa (project S1_TNZ_IPM: Integrated Pest Management (IPM) for Fruit Flies in Tanzania); the joint Food and Agriculture Organisation / International Atomic Energy Agency Programme on Nuclear Techniques in Food and Agriculture (Co-ordinated Research Project on Resolution of Cryptic Species Complexes of Tephritid Pests to Overcome Constraints to the SIT (Sterile Insect Technique) Application 
and International Trade); Fonds voor Wetenschappelijk Onderzoek Vlaanderen (travel grant to MDM to visit the collections of the Stellenbosch University); Government of Finland (CHIESA Project at the International Centre for Insect Physiology and Ecology to RSC: Climate Change Impacts on Ecosystem Services and Food Security in Eastern Africa). We thank the curators of the natural history collections who allowed us to study material and assisted us in our visits: R. Urban and M. Mansell (SANC), P. Addison (SUS), A. Freidberg (TAU), T. Pape (ZMUC). Thanks also to the director of Kenya Forest Service for permission to sample in the forests of Taita Hills; to S. Marshall for allowing us to use the habitus photograph of $C$. sawahilensis sp. nov., to W. Fannes for his assistance in taking images, and to Allen Norrbom and Amnon Freidberg for providing valuable comments to an earlier draft of this article.

\section{References}

Barr N.B. \& McPheron B.A. 2006. Molecular phylogenetics of the genus Ceratitis (Diptera: Tephritidae). Molecular Phylogenetics and Evolution 38: 216-230. http://dx.doi.org/10.1016/j.ympev.2005.10.013

Barr N.B. \& Wiegmann B.M. 2009. Phylogenetic relationships of Ceratitis fruit flies inferred from nuclear CAD and tango/ARNT gene fragments: Testing monophyly of the subgenera Ceratitis (Ceratitis) and C. (Pterandrus). Molecular Phylogenetics and Evolution 53: 412-424. http://dx.doi.org/10.1016/j. ympev.2009.07.008

Burgess N.D., Butynski T.M., Cordeiro N.J., Doggart N.H., Fjeldsa J., Howell K.M., Kilahama F.B., Loader S.P., Lovett J.C., Mblinyi B., Menegon M., Moyer D.C., Nashanda E., Perkin A., Rovero F., Stanley W.T. \& Stuart S.N. 2007. The biological importance of th Eastern Arc Mountains of Tanzania and Kenya. Biological Conservation 134: 209-231. http://dx.doi.org/10.1016/j.biocon.2006.08.015

Clarke A.R. \& Schutze M.K. 2014. The complexities of knowing what it is you are trapping. In: Shelly T., Epsky N., Jang E.B., Reyes-Flores J. \& Vargas R. (eds) Trapping and the Detection, Control, and Regulation of Tephritid Fruit Flies; Lures, Area-Wide Programs, and Trade Implications: 611-632. Springer Verlag, Dordrecht.

De Meyer M. 1996. Revision of the subgenus Ceratitis (Pardalaspis) Bezzi, 1918 (Diptera, Tephritidae, Ceratitini). Systematic Entomology 21: 15-26. http://dx.doi.org/10.1111/j.1365-3113.1996.tb00596.x

De Meyer M. 1998. Revision of the subgenus Ceratitis (Ceratalaspis) Hancock (Diptera: Tephritidae). Bulletin of Entomological Research 88: 257-290. http://dx.doi.org/10.1017/S0007485300025888

De Meyer M. 2000. Systematic revision of the subgenus Ceratitis MacLeay s.s. (Diptera, Tephritidae). Zoological Journal of the Linnean Society 128: 439-467. http://dx.doi.org/10.1111/j.1096-3642.2000. $\underline{\mathrm{tb} 01523 . \mathrm{x}}$

De Meyer M. \& Copeland R. 2001. Taxonomic notes on the subgenera Ceratitis (Hoplolophomyia) and Ceratitis (Acropteromma) (Diptera, Tephritidae). Cimbebasia 17: 77-84.

De Meyer M. \& Copeland R.S. 2005. Description of new Ceratitis MacLeay (Diptera, Tephritidae) species from Africa. Journal of Natural History 39: 1283-1297. http://dx.doi.org/10.1080/00222930400004347

De Meyer M. \& Copeland R. 2009. A new Ceratitis from Kenya (Diptera: Tephritidae). Journal of Afrotropical Zoology 5: 21-26.

De Meyer M. \& Freidberg A. 2006. Revision of the subgenus Ceratitis (Pterandrus) Bezzi (Diptera: Tephritidae). Israel Journal of Entomology 36: 197-315.

De Meyer M., Clarke A.R., Vera M.T. \& Hendrichs J. (eds) 2015a. Resolution of Cryptic species Complexes of Tephritid Pests to Enhance SIT Application and Facilitate International Trade. ZooKeys 540: $1-557$. 
De Meyer M., Delatte H., Ekesi S., Jordaens K., Kalinova B., Manrakhan A., Mwatawala M., Steck G., Van Cann J., Vancikova L., Brizova R. \& Virgilio M. 2015b. An integrative approach to unravel the Ceratitis FAR (Diptera, Tephritidae) cryptic species complex: a review. ZooKeys 540: 405-427. http:// dx.doi.org/10.3897/zookeys.540.10046

Grout T.G. \& Stoltz K.C. 2007. Developmental rates at constant temperatures of three economically important Ceratitis spp. (Diptera: Tephritidae) from southern Africa. Environmental Entomology 36: 1310-1317. http://dx.doi.org/10.1603/0046-225x(2007)36[1310:dracto]2.0.co;2

Hendrichs J., Vera T., de Meyer M. \& Clarke A. 2015. Resolving cryptic species complexes of major tephritid pests. ZooKeys 540: 5-39. http://dx.doi.org/10.3897/zookeys.540.9656

Kimura M. 1980. A simple method for estimating evolutionary rates of base substitutions through comparative studies of nucleotide sequences. Journal of Molecular Evolution 16: 111-120. http:// dx.doi.org/10.1007/BF01731581

Mwatawala M., Virgilio M., Quilici S., Dominic M. \& De Meyer M. 2013. Field evaluation of the relative attractiveness of enriched ginger root oil (EGO)lure and trimedlure for African Ceratitis species (Diptera: Tephritidae). Journal of Applied Entomology 137: 392-397. http://dx.doi.org/10.1111/j.14390418.2012.01744.x

Mwatawala M., Virgilio M., Joseph J. \& De Meyer M. 2015. Niche partitioning among two Ceratitis rosa morphotypes and other Ceratitis pest species (Diptera, Tephritidae) along an altitudinal transect in Central Tanzania. ZooKeys 540: 429-442. http://dx.doi.org/10.3897/zookeys.540.6016

Myers N., Mittermeier R.A., Mittermeier C.G., da Fonseca G.A.B. \& Kent J. 2000. Biodiversity hotspots for conservation priorities. Nature 403: 853-858. http://dx.doi.org/10.1038/35002501

Norrbom A.L., Carroll L.E., Thompson F.C., White I.M. \& Freidberg A. 1999. Systematic database of names. In: Thompson F.C. (ed.) Fruit Fly expert Identification System and Systematic Information Database. Myia 9: 65-251.

Tamura K., Stecher G., Peterson D., Filipski A. \& Kumar S. 2013. MEGA6: Molecular Evolutionary Genetics Analysis version 6.0. Molecular Biology and Evolution 30: 2725-2729. http://dx.doi. org $/ 10.1093 / \mathrm{molbev} / \mathrm{mst} 197$

Tanga C.M., Manrakhan A., Daneel J.-H., Mohamed S.A., Fathiya K. \& Ekesi S. 2015. Comparative analysis of development and survival of two Natal fruit fly Ceratitis rosa Karsch (Diptera, Tephritidae) populations from Kenya and South Africa. ZooKeys 540: 467-487. http://dx.doi.org/10.3897/ zookeys.540.9906

Virgilio M., Backeljau T., Barr N. \& De Meyer M. 2008. Molecular evaluation of nominal species in the Ceratitis fasciventris, C. anonae, C. rosa complex (Diptera: Tephritidae). Molecular Phylogenetics and Evolution 48: 270-280. http://dx.doi.org/10.1016/j.ympev.2008.04.018

Virgilio M., Backeljau T., Emeleme R., Juakali J.L. \& De Meyer M. 2011. A quantitative comparison of frugivorous tephritids (Diptera: Tephritidae) in tropical forests and rural areas of the Democratic Republic of Congo. Bulletin of Entomological Research 101: 591-597.

Virgilio M., Delatte H., Quilici S., Backeljau T. \& De Meyer M. 2013. Cryptic diversity and gene flow among three African agricultural pests: Ceratitis rosa, Ceratitis fasciventris and Ceratitis anonae (Diptera, Tephritidae). Molecular Ecology 22: 2526-2539. http://dx.doi.org/10.1111/mec.12278

Virgilio M., Jordaens K., Breman F.C., Backeljau T. \& De Meyer M. 2012. Identifying insects with incomplete DNA barcode libraries, African fruit flies (Diptera: Tephritidae) as a test case. PLoS ONE 7: e31581. http://dx.doi.org/10.1371/journal.pone.0031581 
Virgilio M., White I.M. \& De Meyer M. 2014. A set of multi-entry identification keys to African frugivorous flies (Diptera, Tephritidae). ZooKeys 428: 97-108. http://dx.doi.org/10.3897/zookeys.428.7366

White I.M. \& Elson-Harris M.M. 1994. Fruit Flies of Economic Significance: Their Identification and Bionomics. CAB International, Wallingford, $601 \mathrm{pp}$.

White I.M., Headrick D.H., Norrbom A.L. \& Carroll 1.E. 1999. Glossary. In: Aluja M. \& Norrbom A. (eds) Fruit flies (Tephritidae): Phylogeny and Evolution of Behavior. CRC Press, Boca Raton, 881-924.

Manuscript received: 7 March 2016

Manuscript accepted: 3 May 2016

Published on: 26 September 2016

Topic editor: Gavin Broad

Desk editor: Kristiaan Hoedemakers

Printed versions of all papers are also deposited in the libraries of the institutes that are members of the EJT consortium: Muséum national d'Histoire naturelle, Paris, France; Botanic Garden Meise, Belgium; Royal Museum for Central Africa, Tervuren, Belgium; Natural History Museum, London, United Kingdom; Royal Belgian Institute of Natural Sciences, Brussels, Belgium; Natural History Museum of Denmark, Copenhagen, Denmark; Naturalis Biodiversity Center, Leiden, the Netherlands. 